\title{
PEMBUATAN TAMAN BACAAN MASYARAKAT SEBAGAI SARANA PEMBELAJARAN PADA MASA PANDEMI COVID 19 DI PERUMAHAN BUKIT MEKAR WANGI KECAMATAN TANAH SAREAL KOTA BGOR
}

\author{
Herawati Sri Septina ${ }^{1}$ dan Abdul Karim Halim ${ }^{2}$ \\ hfitrifadilah@gmail.com $^{1}$ \\ abdulkarimhalim7@gmail.com ${ }^{2}$ \\ Fakultas Keguruan dan Ilmu Pendidikan Universitas Ibn Khaldun Bogor ${ }^{1,2}$
}

\begin{abstract}
Taman Bacaan Masyarakat atau dikenal dengan singkatan TBM adalah perpustakaan skala kecil yang dikenal sebagai sudut baca, rumah baca, rumah pintar, dan sebagainya. TBM bukan sekedar tempat belajar, tapi juga harus menjadi motor penggerak aktivitas sosial. TBM diperlukan sebagai tempat belajar yang lebih menyenangkan, dan diharapkan menjadi sarana yang efektif untuk para siswa tetap belajar dimasa pandemi Covid19. Secara umum tujuan berdirinya Taman Bacaan Masyarakat adalah untuk memudahkan masyarakat dalam mengakses dan memperoleh bahan bacaan. Metode penelitian yang digunakan adalah studi lapangan ( field research) yaitu mengadakan pengamatan secara langsung untuk memperoleh informasi yang diperlukan. Hasil Penelitian menunjukkan bahwa Taman Bacaan Masyarakat yang ada di Perumahan Bukit Mekar Wangi dibuat dengan beberapa program kegiatan yang ada. Pertama, Program Literasi, yang isi kegiatannya adalah pelatihan kepenulisan cerita khusus untuk anak-anak. Kedua, Program Mendongeng dengan aktifitas mendengar dan menyimak cerita yang dibacakan oleh tutor yang ada. Kegiatan mendongeng ini dapat membantu orangtua yang kesulitan dalam mengatur dan meminimalisir aktifitas penggunaan gadget pada anak-anak dirumah. Ketiga, Perpustakaan Kebun yang dapat menjadi sumber pengetahuan bagi masyarakat melalui informasi yang rinci dan mendalam tentang tanaman, pohon atau tumbuhan yang ada disekitar TBM. Kuliah Kerja Nyata Gagasan tertulis Mandiri yang kami laksanakan di tempat tersebut mencoba memberikan sedikit peran, melalui sumbangan pemikiran dalam bentuk Gagasan tertulis untuk diterapkan pada aktititas kelompok mereka dan sekaligus kami membuatkan Kawasan Demontrasi Plot pada Lahan Kawasan Terbuka Hijau yang ada pada lingkungan mereka.
\end{abstract}

\section{Keyword : Taman Bacaan Masyarakat, Sarana Pembelajaran, Covid19}

\section{PENDAHULUAN}

Tujuh (7) bulan sudah kegiatan pembelajaran tahun 2020 dilakukan melalui sistem pembelajaran jarak jauh (PJJ). Sekolah di tengah pandemi Covid-19 para siswa 'tertinggal' secara akademik (dilansir dari BBC NEWS.com). Menurut pengamat pendidikan, Keterbatasan fasilitas pendukung hingga ketidaksiapan siswa belajar di rumah, membuat sistem itu "belum efektif" dan keadaannya yang mengakibatkan capaian akademik siswa "tertinggal". Fasilitas pendukung belajar 
dirumah bisa jadi adalah buku-buku yang dapat digunakan sebagai referensi untuk belajar siswa yang belum tersedia, sehingga siswa hanya mengandalkan buku yang diberikan sekolah sebagai satu-satunya bahan belajar dirumah.

Berdasarkan Hasil pengamatan, penulis mendapati para siswa yang merasa jenuh dengan sistem sekolah daring yang notabane nya para siswa hanya mengerjakan tugas-tugas yang relatif lebih banyak daripada tatap muka. Tak sedikit yang dalam proses pengerjaan tugas-tugas tersebut diwarnai dengan ketegangan antara ibu dan anak dirumah. Baik karena anak yang malas-malasan dalam mengerjakan, atau ibu yang kurang memahami tugas yang diberikan. Sehingga para siswa tampak terpaksa dalam melakukan proses belajar dirumah. Hal ini sangat membuat batin menangis, karena bila hal demikian terus terjadi akan berdampak buruk pada mental para siswa khususnya yang masih berada pada usia sekolah dasar. Disamping itu, sebagian siswa sekolah dasar lebih banyak menghabiskan waktunya untuk bermain ketimbang belajar, karena merasa bahwa sekolah masih diliburkan.

Sebagai upaya menghindari para siswa dari kejenuhan belajar daring di masa pandemic covid19 dan agar mereka tetap bisa belajar dari banyak sumber maka penulis mengambil gagasan tentang Taman Bacaan Masyarakat (TBM) sebagai sarana belajar masyarakat khususnya para siswa. Taman Bacaan Masyarakat atau dikenal dengan singkatan TBM adalah perpustakaan skala kecil yang dikenal sebagai sudut baca, rumah baca, rumah pintar, dan sebagainya. TBM bukan sekedar tempat belajar, tapi juga harus menjadi motor penggerak aktivitas sosial. Pada masa pandemic seperti saat ini, TBM diperlukan sebagai tempat belajar yang lebih menyenangkan, dan diharapkan menjadi sarana yang efektif untuk para siswa tetap belajar dimasa pandemic.

Taman Bacaan Masyarakat (TBM) yang digagas bukan sekedar sebagai tempat atau sarana untuk membaca saja. Selain dapat menjadi tempat masyarakat membaca buku, harapannya TBM ini bisa menjadi tempat untuk meningkatkan keterampilan hidup baik anak-anak maupun orangtua melalui berbagai kegiatan yang akan dirancnag, seperti latihan menulis, mendongeng, dan bahkan bisa mendapatkan tata cara menanam sayuran, atau tanaman obat dengan teknik aqua ponic yang mudah diikuti. Sehingga tempat ini dikatakan sebagai Pusat Belajar Masyarakat, dan masyarakat dapat meningkatkan kualitas hidupnya melalui tempat ini. Terlebih di masa pandemic covid 19 seperti sekarang ini, peserta didik dapat menambah pengetahuannya dengan bahan bacaan yang tersedia di TBM, menjadi tempat hiburan yang mengedukasi dan juga bagi masyarakat umum bisa mengikuti berbagai kegiatan yang berguna untuk memenuhi kebutuhan pangannya melalui dapur hidup dan apotik hidup yang tersedia di Pusat Belajar Masyarakat ini. Oleh Karena itu Penelitian Pengabdian Masyarakat yang dipilih adalah "Pembuatan Taman Bacaan Masyarakat Sebagai Sarana Pembelajaran dimasa Pandemi Covid19" di Perumahan Bukit Mekar Wangi Dari latar belakang diatas rumusan masalah yang ditemukan adalah Taman Bacaan Masyarakat dapat menjadi Sarana Pembelajaran masyarakat dimasa Pandemic covid-19. Apa pun nama dan bentuk kegiatan yang kita lakukan, sudah pasti menuju tujuan yang sudah kita tetapkan diawal kegiatan dimaksud yang kita lakukan. Berikut ini adalah tujuan dari penelitian pengabdian pada masyarakat 
yang dilakukan, sebagai berikut (i) Meningkatkan pengetahuan siswa-siswi Masyarakat di masa Pandemic Covid-19, (ii) Membantu Mengurai permasalahan pendidikan yang ada di sekitaran Perumahan Bukit Mekar Wangi di masa

\section{METODE}

Penelitian pengabdian masyarakat ini termasuk penelitian lapangan ( field research) yaitu Suatu penelitian yang dilakukan secara sistematis dengan mengangkat data yang ada dilapangan (Suharsimi Arikunto: 1995). Penelitian lapangan merupakan penelitian kualitatif di mana peneliti mengamati dan berpartisipasi secara langsung dalam penelitian skala sosial kecil dan mengamati budaya setempat. Secara sederhana Metode pengamatan penelitian lapangan ( field research) dapat didefinisikan yaitu mengadakan pengamatan secara langsung untuk memperoleh informasi yang diperlukan. Metode field research dilakukan guna mendapatkan hasil yang akurat dan pasti, dimana peneliti ikut bergaul dan melakukan kegiatan sosial lainnya demi mendapatkan kesimpulan yang sesuai dari apa yang ada dilapangan.

\section{HASIL dan PEMBAHASAN}

Dengan menggunakan metode penelitian Studi Lapangan yang dilakuukan dengan harapan dapat memberikan solusi dalam mengatasi permasalahan pendidikan dimasa pandemi Covid19, dengan didapat hasil sebagai berikut :

\section{A. Pemilihan Lokasi}

Penelitian pengabdian masyarakat ini dilakukan di Perumahan Bukit Mekar Wangi dan sekitarnya, dengan memanfaatkan Lahan Kawasan Ruang Terbuka Hijau, dengan tujuan untuk pandemic Covid 19, (iii) Memberikan Fasilitas belajar kepada masyarakat umum melalui adanya Koleksi buku-buku dan koleksi tanaman yang ada di perpustakaan kebun.

Penelitian ini dilakukan dengan melalui 3 tahapan dengan kurun waktu 4 minggu yaitu pada tanggal 02 September 2020 dilingkungan Perumahan Bukit Mekar Wangi kecamatan Tanah Sareal Kota Bogor, dengan tahap sebagai berikut :

Tahap Pertama, peneliti melakukan observasi untuk mengetahui dan mengamati kondisi di lingkungan Perumahan Bukit Mekar Wangi Kota Bogor terkait kondisi belajar masyarakat khususnya siswa-siswi dimasa Pandemi Covid-19.

Tahap Kedua, Peneliti merencakan melalui gagasan tertulis berupa konsep taman bacaan masyarakat yang akan dibuat.

Tahap Ketiga, yaitu penyediaan tempat, koleksi buku-buku, dan juga fasilitas lainnya yang nantinya akan diakses oleh masyarakat sekitar Perumahan Bukit Mekar Wangi.

menjadikan Taman Bacaan Masyarakat sebagai Sarana Pembelajaran dalam mengatasi Permasalahan belajar di era Covid-19 ini.

\section{B. Pengumpulan Data}

Teknik pengumpulan data pada penelitian ini adalah Observasi, yaitu dengan cara mengamati secara langsung untuk memperoleh permasalan yang berkaitan dengan pembelajaran di masa pandemi dan dokumentasi lapangan serta ditambah dengan data sekunder yang diperoleh dari 
buku-buku yang relevan dengan fokus penelitian yaitu Taman Bacaan Masyarakat.

\section{Analis Data}

Setelah observasi selesai dilakukan dan data yang dibutuhkan terkumpul, peneliti

\section{PEMBAHASAN}

Taman Bacaan Masyarakat Mekar Wangi sebagai Sarana Belajar Masyarakat di era Pandemik Covid-19 ini setidaknya memiliki Program sebagai berikut :

\section{Program Literasi}

Kemampuan literasi dasar merupakan bagian dari keterampilan berbahasa dalam kurikulum sekolah (Tarigan, $2015:$ 1). Hal tersebut dikuatkan oleh Safitri (2019: 154) yang menyatakan bahwa membaca menjadi salah satu keterampilan berbahasa yang memiliki peran penting dalam kehidupan berbahasa. Jika intensitas membaca rendah, maka keterampilan berbahasa yang lain seperti menulis, menyimak, berfikir kritis juga akan terpengaruh. TBM ini menjadi tempat yang tepar bagi siswa maupun masyarakat yang ingin membaca buku secara langsung atau meminjam buku untuk dibawa pulang.

Program literasi ini tidak hanya memfokuskan pada kemampuan membaca seseorang melalui buku-buku yang tersedia di TBM, namun juga dimaksudkan pada peningkatan kemampuan menulis para siswa ataupun masyarakat yang menjadi pengunjung TBM ini.

Dalam program literasi ini Mereka dapat mengasah kemampuan menulis melalui kegiatan "menulis cerita sederhana" yang akan dipandu oleh pengelola TBM. Meski sedang dihadapkan dengan kondisi pandemi seperti saat ini, Kegiatan ini berguna untuk membuat anakanak lebih produktif dalam mengisi waktunya dengan hal yang bermanfaat. mengklasifikasikan data menjadi sesuatu yang dapat dikelola yaitu dengan adanya "Taman Bacaan Masyarakat sebagai Sarana Pembelajaran Dimasa Pandemi Covid-19”.

Dimasa pandemi seperti sekarang, program literasi ini tetap bisa dilakukan dengan pengaturan yang sesuai prokol kesehatan yang berlaku. Jadi selain membantu mengurangi masyarakat bepergian jauh, program literasi kepenulisan yang digagas juga dapat menjadi solusi untuk menjaga minat siswasiswi yang terdampak corona dalam soal belajar.

\section{Program Mendongeng}

Selain Program Literasi dalam hal kepenulisan, Taman Bacaan Masyarakat ini memiliki kegiatan atau program literasi yang lainnya yaitu Mendongeng. Program ini disediakan bagi kalangan yang belum terbiasa atau tidak suka membaca buku. Sehingga, masyarakat tetap memiliki alternatif kegiatan yang ingin mereka lakukan di TBM selain membaca buku.

Mendongeng adalah menuturkan sesuatu yang mengisahkan tentang perbuatan atau suatu kejadian dan disampaikan secara lisan dengan tujuan membagikan pengalaman dan pengetahuan kepada orang lain (Bachri, 2005;10).

Dalam kegiatan mendongeng ini pengunjung baik anak-anak maupun orang dewasa dapat mengikuti dan menyimak cerita-cerita yang disampaikan secara menarik oleh tutor yang expert di bidang ini.

Kegiatan mendongeng ini dapat membantu orangtua yang kesulitan dalam mengatur dan meminimalisir aktifitas penggunaan gadget pada anak-anak 
dirumah. Meski saat ini memang era digital tetapi terlalu membebaskan anak-anak dengan gadget dapat berdampak buruk bagi kesehatannya. Maka dari itu, alternatif mendongeng ini dapat ditawarkan kepada mereka yang merasa bosan dan butuh sesuatu yang menghibur.

Kegiatan mendongeng tidak sekedar bersifat menghibur, namun juga memiliki tujuan. Menurut Priyono (2001:15) mendongeng mempunyai tujuan: a) Merangsang dan menumbuhkan imajinasi dan daya fantasi anak secara wajar. b) Mengembangkan daya penalaran sikap kritis serta kreatif. c) Mempunyai sikap kepedulian terhadap nilai-nilai luhur budaya bangsa. d) Dapat membedakan perbuatan yang baik dan perlu ditiru dengan yang buruk dan tidak perlu dicontoh. e) Punya rasa hormat dan mendorong terciptanya kepercayaan diri dan sikap terpuji pada anak.

\section{Perpustakaan Kebun}

Taman Bacaan Masyarakat yang ada di Perumaham Mekar Wangi menyediakan koleksi buku-buku yang dibaca oleh semua kalangan, mulai dari anak-anak hingga orang dewasa. Tetapi, selain koleksi bukubuku bacaan, adapula koleksi tumbuhtumbuhan baik tanaman hias maupun tanaman obat serta pohon-pohon yang beragam jenis dan manfaatnya yang bisa

\section{SIMPULAN}

Berdasarkan hasil pembahasan di Atas dapat disimpulkan bahwa Taman Bacaan Masyarakat adalah sebuah wadah yang didirikan oleh masyarakat atau pemerintah guna memberikan akses layanan akses bacaan Masyarakat disekitar TBM, ataupun sebagai sarana untuk pembelajaran sepanjang masa dalam rangka meningkatkan kemampuan hidup disebut sebagai perpustakaan kebun.

Perpustakaan kebun yang ada di TBM ini dapat menjadi sumber pengetahuan bagi masyarakat melalui informasi yang rinci dan mendalam tentang masing-masing tanaman, pohon atau tumbuhan yang ada disekitar. Sehingga, pengunjung TBM dapat menimbun informasi dengan hanya menelusuri sepanjang jalan menuju ke Taman Bacaan Masyarakat.

Koleksi tumbuhan, tanaman maupun pohon-pohon yang ada disana akan diberikan label berisikan informasi jelas tentang jenis pohon, asal tumbuhan, manfaatnya, serta keterangan lain yang bisa menambah pengetahuan para pengunjung. Hal ini dapat menjadi daya tarik tersendiri, karena setiap orang yang mengunjungi akan mendapat suguhan tempat-tempat menarik yang bisa dijadikan sebagai sarana belajar yang menarik dan tempat rekreasi yang mengedukasi.

Dengan demikian anak-anak yang terdampak pandemi dapat mengunjungi tempat ini sebagai tempat yang bisa memberikan fasilitas pembelajaran yang nyata melalui tumbuhan, pohon atau tanaman obat yang ada. Sehingga, menambah pengetahuan mereka tentang jenis dan bentuk pohon yang mungkin selama ini belum mereka ketahui wujud aslinya.

masyarakat. Tujuan dari adanya TBM menurut (Kementerian Pendidikan dan Kebudayaan, 2013) adalah untuk : (1) Meningkatkan kemampuan keberaksaraan dan keterampilan membaca, (2) Menumbuhkembangkan minat dan kegemaran membaca, (3) Membangun masyarakat membaca dan belajar,(4) Mendorong mewujudkan masyarakat 
pembelajar

sepanjang

hayat,

Mewujudkan kualitas dan kemandirian masyarakat yang berpengetahuan, berketerampilan, berbudaya maju, dan beradab.

Pada Era Pandemiic Covid-19 saat ini TBM di tujukan sebagai sarana belajar para siswa yang tengah menjalankan pembelajaran jarak jauh (PJJ). Untuk memenuhi kebutuhan baca para siswa agar lebih memahami apa yang sedang dipelajari.

Taman Bacaan Masyarakat ini selain memberikan fasilitas berupa koleksi bukubuku yang dapat dibaca atau di pinjam. TBM ini juga Setidaknya memiliki program-program yang digagas sebagai berikut :

1. Program Literasi

2. Program Mendongeng

3. Perpustakaan Kebun

Dengan demikian TBM dapat menjadi sarana Belajar Masyarakat khususnya siswa-siswi yang terdampak pandemi bisa melalui berbagai fasilitas kegiatan yang ada disini. Bagi siswa-siswi yang gemar membaca koleksi buku-buku yang ada di perpustakan TBM bisa dibaca disana atau dipinjamkan untuk dibaca dirumah, sedangkan bagi pengunjung yang tidak terbiasa membaca dapat mengikuti pilihan program yang tersedia disana. Oleh karena itu kebutuhan belajar masyarakat khususnya siswa-siswi yang terdampak pandemi disekitaran Perumahan Mekar Wangi tetap bisa terpenuhi dengan baik melalui Taman Bacaan Masyarakat ini.

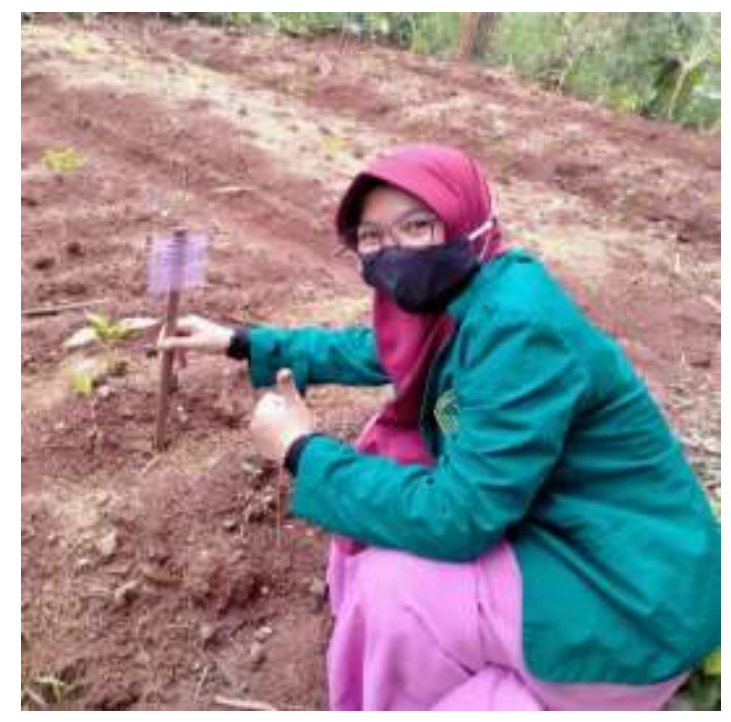

Gambar 1. Pemberian label nama pada tanaman Cabai

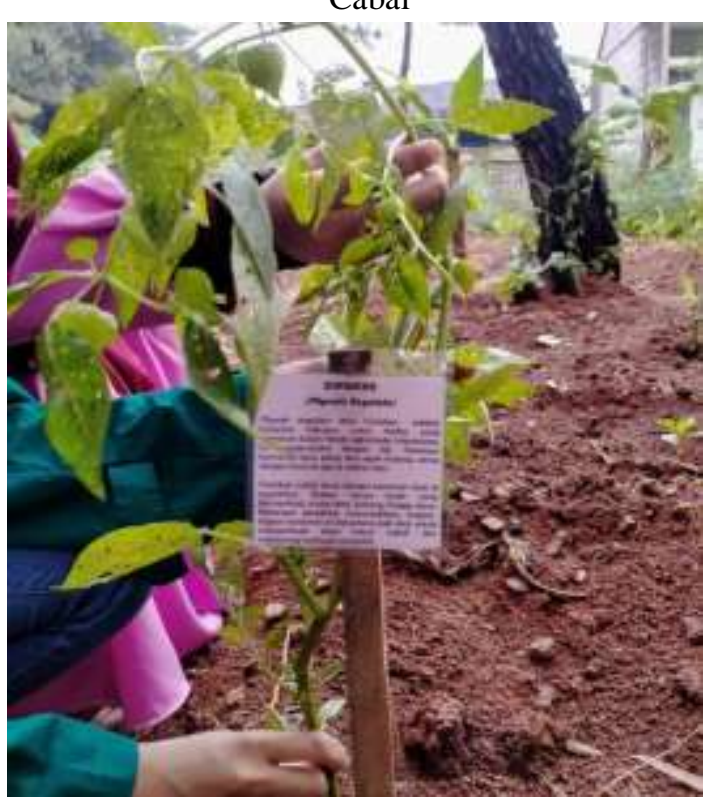

Gambar 2. P emberian label nama pada tanaman Cabai 


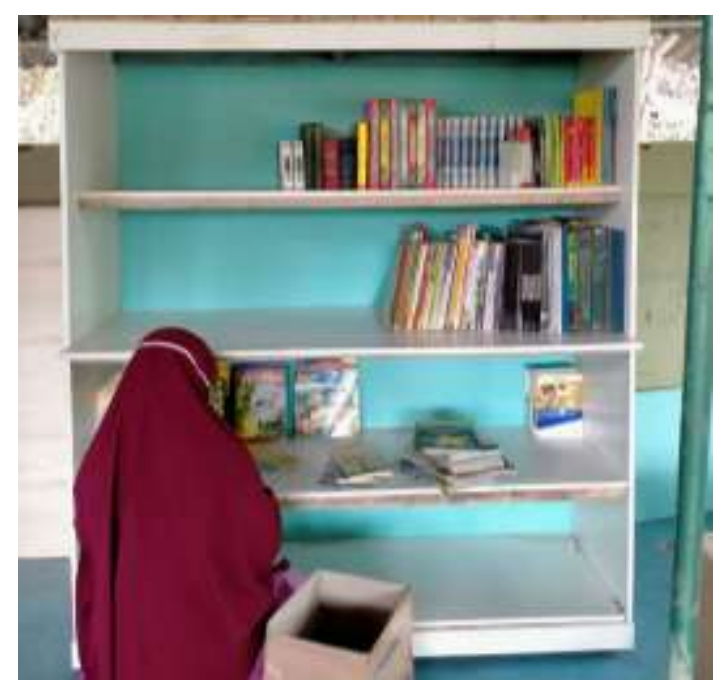

Gambar 3. Penyusunan koleksi buku-buku, majalah, dsb untuk perpustakaan umum

\section{DAFTAR PUSTAKA}

Dwiyantoro, Peran Taman Bacaan Masyarakat Mata Aksara Dalam Menumbuhkan Minat Baca Pada Masyarakat. Jurnal Kajian Informasi \& Perpustakaan Vol. 7, No. 1 (Juni 2019) 19-32

Maulida, Riri Rizky. 2017. Peran Bacaan Masyarakat (TBM) warabal dalam mengembangkan Minat Baca Anak Melalui Pendar dan Dongeng. Skripsi. Tidak diterbitkan. Fakultas Adab dan Humaniora. UIN Syarif Hidayatullah: Jakarta.

Saepudin, E. (2016). Tingkat Budaya Membaca Masyarakat (Studi Kasus Pada Masyarakat Di Kabupaten Bandung). Jurnal KajianInformasi dan Perpustakaan, 3(2), 276. Retrieved from http://jurnal.unpad.ac.id/jkip.

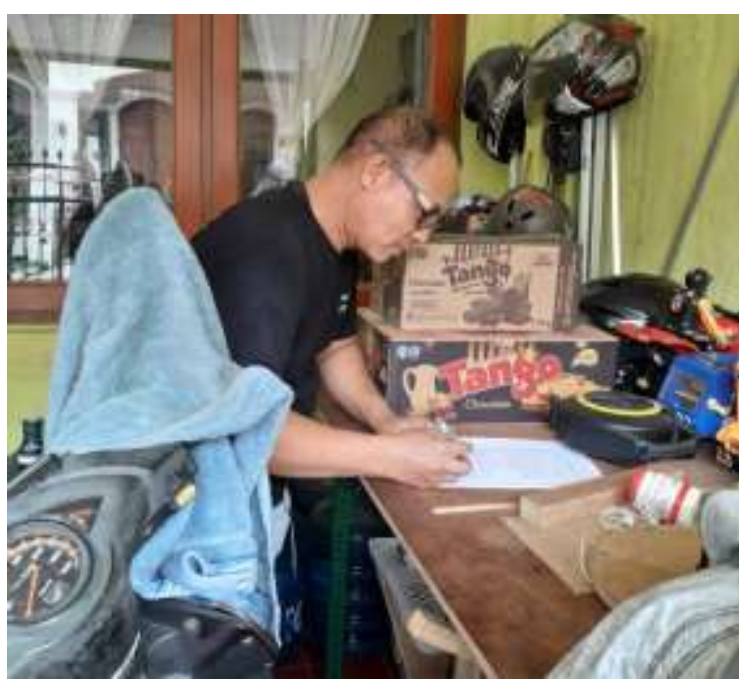

Gambar 4. Penandatangan Surat Mitra kerja bersama Sekretaris Bank Sampah Perum Bukit Mekar Wangi

Sungkowo Edy Mulyono, M. Misriyani. 2019. Pengelolaan Taman Baca Masyarakat. Journal of Nonformal Education and Community Empowerment. Volume 3 (2): 160172.

Yanto, Andri, Saleha Rodiah dan Elnovani Lusiana. 2016. Model Aktivitas Gerakan Literasi Berbasis Komunitas di Sudut Baca Soreang. Jurnal Kajian Informasi \& Perpustakaan. Volume 2 (Nomor 1), hlm 107-118.

http://pauddikmassumbar.kemdikbud.go.id lartikel/28/taman-bacaanmasyarakat-tbm-sebagai-literasiinformasi-bagi-masyarakat ( di akses tanggal 9 september 2020)

Rukiyah, 2018. Dongeng, Mendongeng, dan Manfaatnya. ANUVA. Volume 2 (1), hlm 99 -106 